\title{
Az európai védelmi kiadások két olvasata
}

\begin{abstract}
2019 végén előbb a NATO, ${ }^{1}$ majd az Európai Védelmi Ügynökség (European Defence Agency - EDA) is ${ }^{2}$ nyilvánosságra hozta aktuális, a védelmi kiadások trendjeire vonatkozó kimutatásait. Bár mindkét szervezet nemzeti adatszolgáltatás alapján dolgozik, adatgyüjtési és -elemzési módszertanuk és a figyelembe vett tagállamok köre valamelyest eltérő, igy az összegszerü kimutatások nem (is) egyez(het)nek, a trendek azonban ugyanarra mutatnak rá: az európai államok 2014 óta jelentős mértékben növelték védelmi kiadásaikat. Az elemzés e két beszámoló következtetéseit hasonlítja össze és értékeli a trendek mozgatórugóit.
\end{abstract}

Kulcsszavak: költségvetés, védelmi kiadások, EDA, NATO, Európa, kutatás-fejlesztés

\section{Csiki Varga Tamás: Two readings of European defence expenditures}

At the end of 2019, first NATO, then the European Defence Agency published their most current reports on defense expenditure trends. Even though both organisations work with national data provided, and their sampling and analytical methodology, as well as the set of member countries, somewhat differ, thus their nominal results cannot fully coincide, trends in both cases are similar and lead to the same conclusion: European countries have significantly increased their defence spending since 2014. This paper compares the conclusions of the two reports and offers an analysis of the drivers behind the trends.

Keywords: expenditure, defense spending, EDA, NATO, Europe, research and development

\section{Az EDA kimutatása}

Az Európai Védelmi Ügynökség (a továbbiakban: EDA) adatai alapján 2007-2013 között a gazdasági válság hatására 11\%-kal csökkentek az Európai Unió tagállamainak védelmi kiadásai, majd a 2014-2018 közötti években folyamatosan növelték azokat. Mint arra a védelmi ügynökség már egy évvel korábban is rámutatott, a NATO-tagállamok walesi vállalásához köthető 2\%-os GDP-arányos kiadásszintjétől akkor nominálértéken 85-90 milliárd euróval, az „elvárt” összeg mintegy harmadával maradtak el. ${ }^{3}$ 2017-hez képest a következő

1 Defence Expenditure of NATO Countries (2013-2019), [online], 2019. 11. 12. Forrás: NATO Public Diplomacy Division [2020. 01. 23.]

2 Defence Data 2017-2018. Key Findings and Analysis, [online], 2019. 12. 16. Forrás: European Defence Agency [2020. 01. 23.]

3 Defence Data 2016-2017. Key Findings and Analysis, [online], 2018. 09. 07., 7. o. Forrás: European Defence Agency [2020. 01. 23.] 
évben 3\%-kal nőttek e kiadások - összesen 223 milliárd euró értékre - és így 2018-ban közelítették meg újra a válság előtti, 2007-es szintet (1. ábra). Bár a védelmi kiadások fokozatosan visszatértek a tíz évvel ezelőtti válságot megelőző szintre, az adatokból az is jól látható, hogy a védelmi költségvetés dinamikusan csökkent, amikor a tagállamok nemzeti összterméke (GDP) a recesszió hatására csökkent, viszont csak lomhán indult növekedésnek abban az időszakban is, amikor a gazdasági mutatók már javultak. 2014 óta láthatjuk azt, hogy a GDP és a védelmi kiadások trendje ismét párhuzamosan növekszik. Így az EU tagállamai átlagosan nemzeti össztermékük 1,4\%-át költötték védelemre 2018-ban.

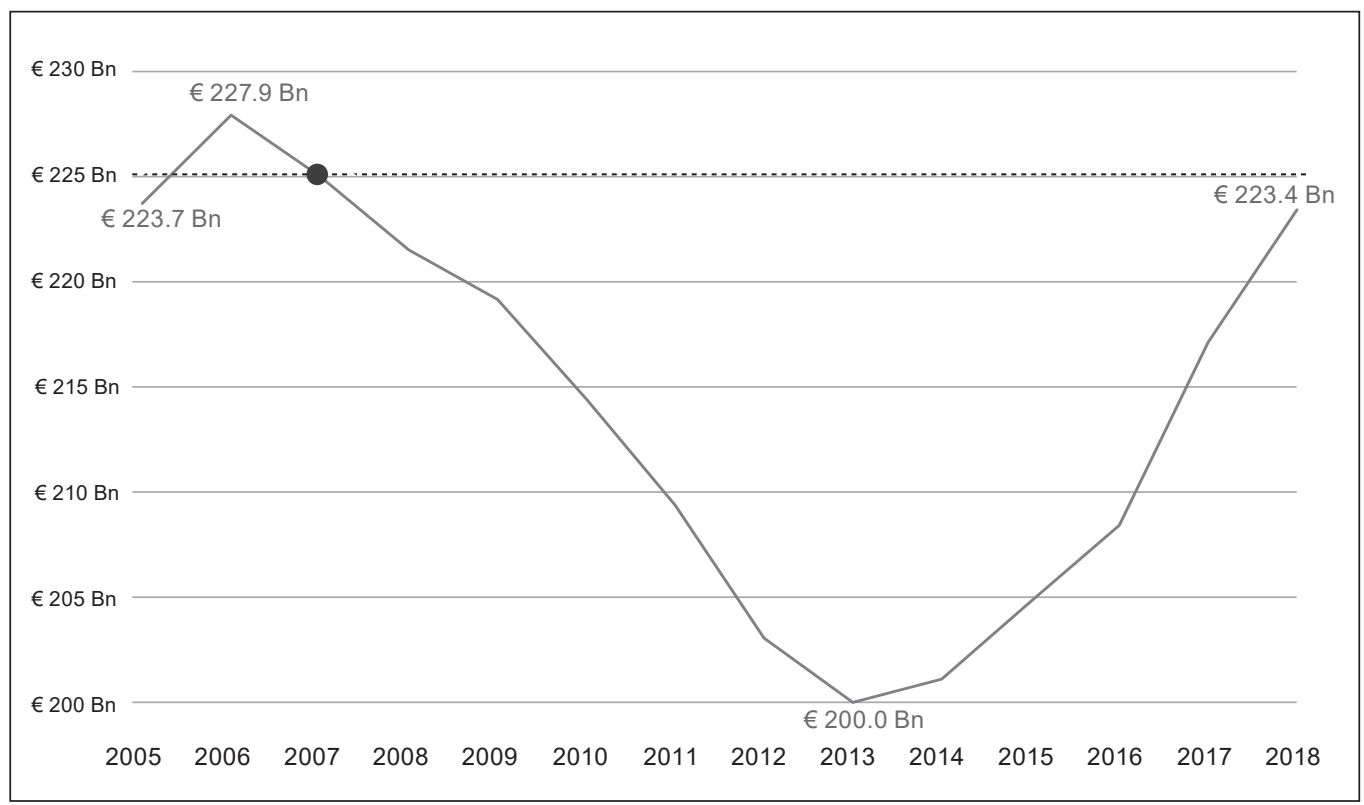

1. ábra: Az EU tagállamainak védelmi kiadási trendje, 2005-2018. A trend viszonyítási pontja a 2007-es év (zöld pont).

Forrás: EDA Defence Data 2017-2018. Key Findings and Analysis: 3. o.

A képességfejlesztésre fordított források 2007-2014 között 22\%-kal csökkentek, 35,8 milliárd euró szinten érve el a mélypontot, majd 2018-ra folyamatos emelkedéssel 44,5 milliárd euróra emelkedtek, ezzel még mindig nem érve el a 2010-es szintet (46,9 milliárd euró). Arányaiban 2018-ban az EU-tagállamok védelmi költségvetésük 19,9\%-át költötték képességfejlesztésre, ami éppen elmarad a 20\%-os NATO-vállalástól - és jelentősen az amerikai (30\% - 160,5 milliárd euró) és a kínai képességfejlesztés ( $41 \%$ - 60 milliárd euró) becsült értéke mögött. ${ }^{4}$

4 Defence Data 2017-2018. Key Findings and Analysis: 4. o. 


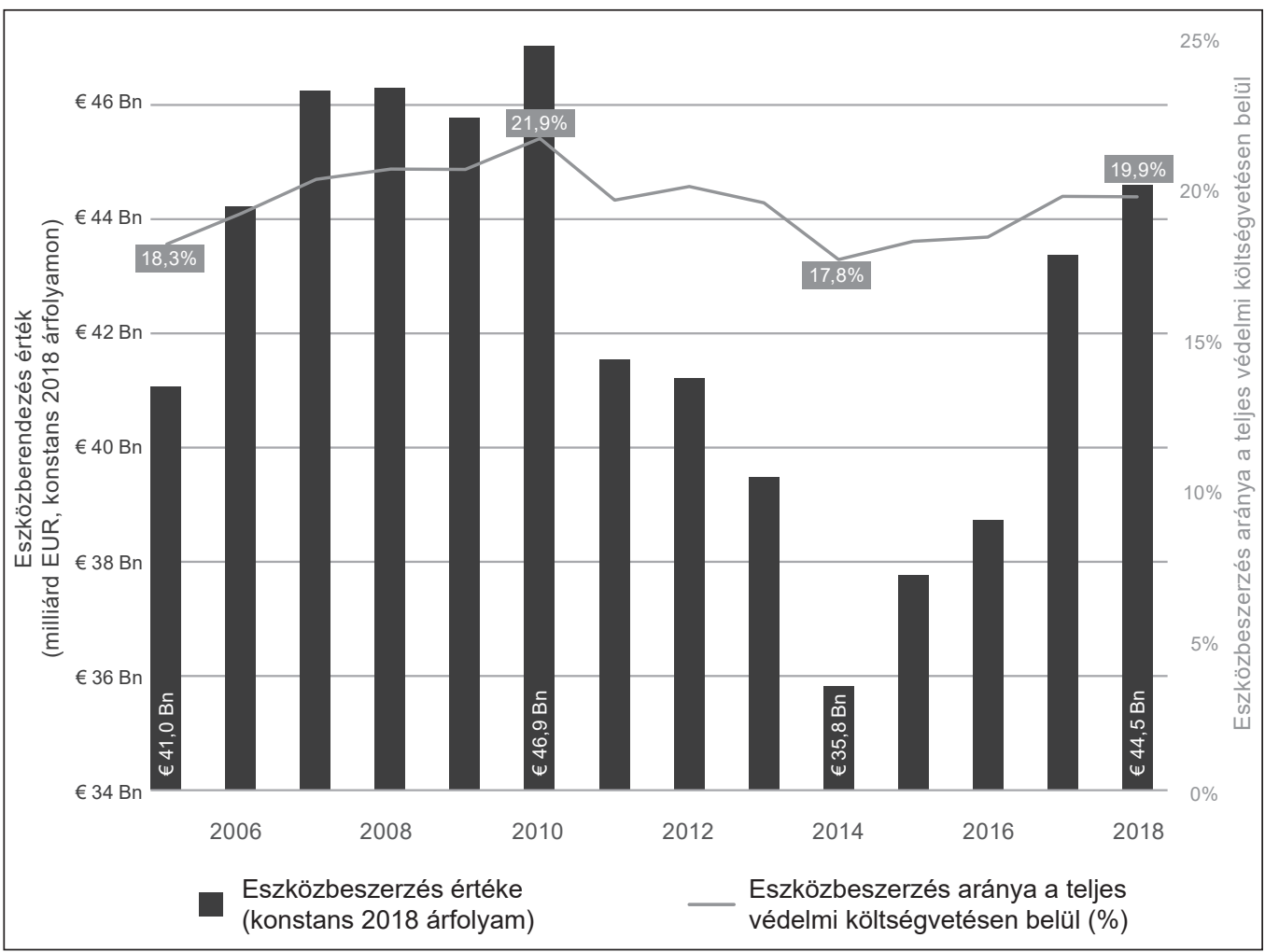

\section{2. ábra: Az EU tagállamainak eszközbeszerzésre fordított forrásai és azok aránya a teljes védelmi költségvetésen belül, 2005-2018.}

Forrás: EDA Defence Data 2017-2018. Key Findings and Analysis: 5.

A modernizációs célú képességfejlesztési kiadásoknál is lassabban állt újra növekedési pályára a védelmi kutatás-fejlesztés finanszírozása. A védelmi kutatás-fejlesztés $(K+F)$ kiadások 2006-2016 között 3 milliárd euróról 1,6 milliárd euróra csökkentek - majd 2018-ban kétéves emelkedést követően is csak 2,1 milliárd euróra nőttek (3. ábra). Mindezt úgy, hogy bár kevésbé közismert, de az EDA védelmi miniszteri szintű vezető testülete 2007-ben közös keretmegállapodás ${ }^{5}$ értelmében azt is elfogadta, hogy a védelmi költségvetésük 2\%-át kutatás-fejlesztésre költik, de korábban a legmagasabb arány (2006) is csak $1,3 \%$ volt, 2018-ban pedig csupán $0,9 \%$. A K + F kiadások megfelelő szinten tartása tudná biztosítani az új kihívásokra történő reagálás és a legmodernebb technológiákhoz és harceljárásokhoz történő adaptáció képességét. Az Unió szintjén az is látható, hogy szük azon államok köre, akik érdemben költenek védelmi kutatás-fejlesztésre: 2018-ban csak 4 EDAtagállam költött a védelmi kiadások $1 \%$-ánál többet e célra, sőt négy ország a teljes védelmi K + F $85 \%$-át, 8 ország már $96 \%$-át lefedi, azaz a többi összesen is alig költ kutatásra.

5 Benchmarks, [online], 2019. 12. 16. Forrás: European Defence Agency [2020. 01. 23.] 
Összehasonlításképpen: az Egyesült Államok az EDA becslése szerint 2017-ben 11,9 milliárd euró értékben költött védelmi K + F-re. ${ }^{6}$

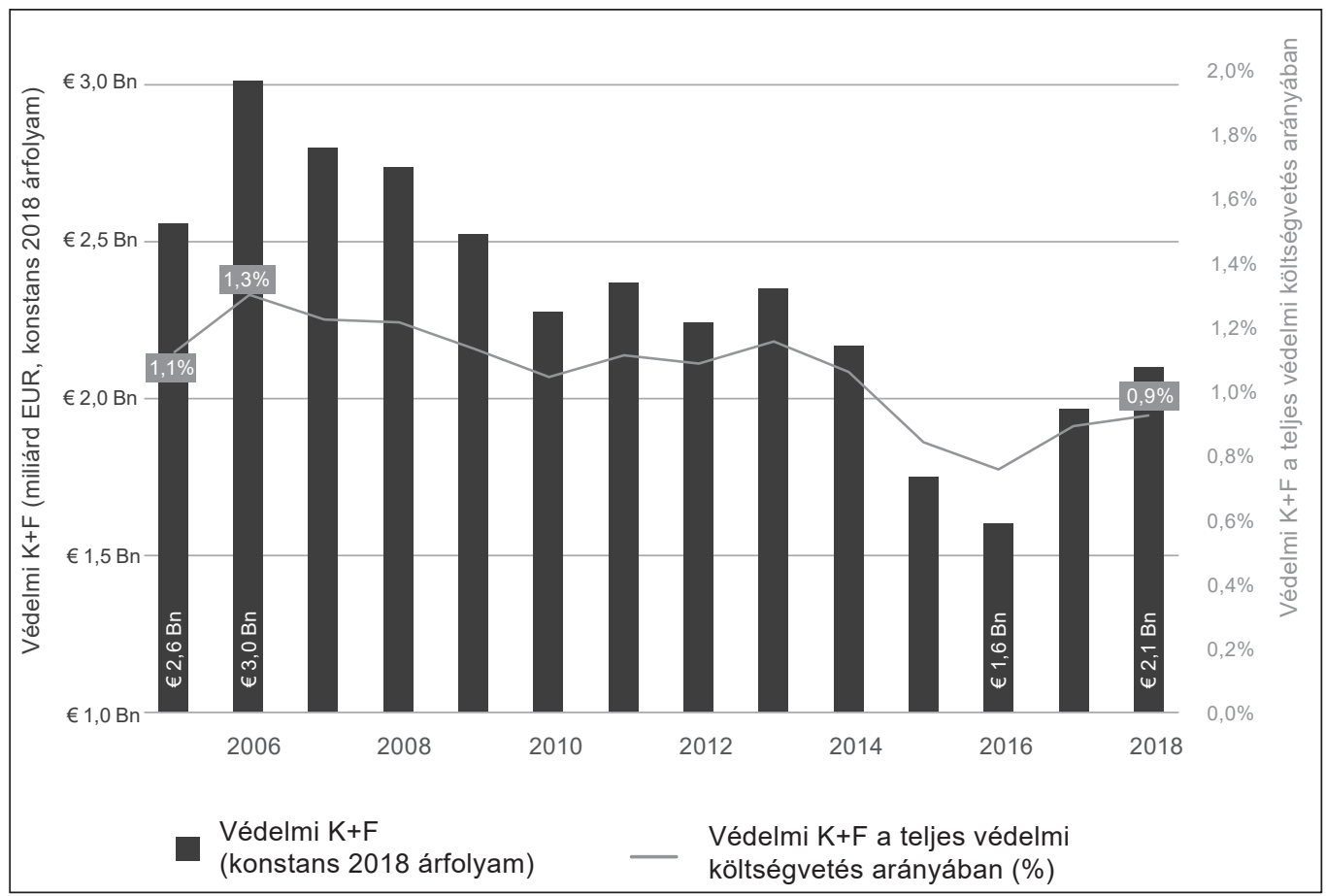

\section{3. ábra: Az EU tagállamainak védelmi kutatás-fejlesztési kiadásai és azok aránya a teljes védelmi költségvetésen belül, 2005-2018.}

Forrás: EDA Defence Data 2017-2018. Key Findings and Analysis: 7.

Bár mind 2009 után a forrásszűkösség időszakában, mind 2014 után, amikortól jelentős modernizációs programok kezdődtek Európában, politikai szinten nagy lendülettel igyekeztek az EU szervei a többnemzeti képességfejlesztést előtérbe helyezni, például az állandó strukturált kezdeményezés (PESCO) keretében, ennek eredménye a számok tükrében nem igazán látszik. A technológiai tudás (know-how) megosztása és a fejlesztési-beszerzési források megosztott felhasználása nagyobb kutatás-fejlesztési, gyártási vagy vásárlőerökapacitást eredményezhetne - hangzottak a többnemzeti képességfejlesztés mellett szóló érvek -, míg kétségtelen, hogy kölcsönös függőségeket is teremtene.

Az EDA-kimutatás szerint a többnemzeti keretben zajló képességfejlesztésre fordított költségvetés 2009-2011 között 8 milliárd euró szintről 2013-ra 4,7 milliárd euróra csökkent, majd 2018-ra 6,4 milliárd euróra emelkedett - de még így sem érte el a 2008 előtti szintet sem arányaiban, sem nominálértéken. 2018-ban az EDA-tagállamok képességfej-

6 Defence Data 2017-2018. Key Findings and Analysis: 6. 
lesztési programjainak 17,8\%-a zajlott többnemzeti keretben - szemben a 35\%-os EDAcélkitüzéssel (4. ábra). ${ }^{7}$

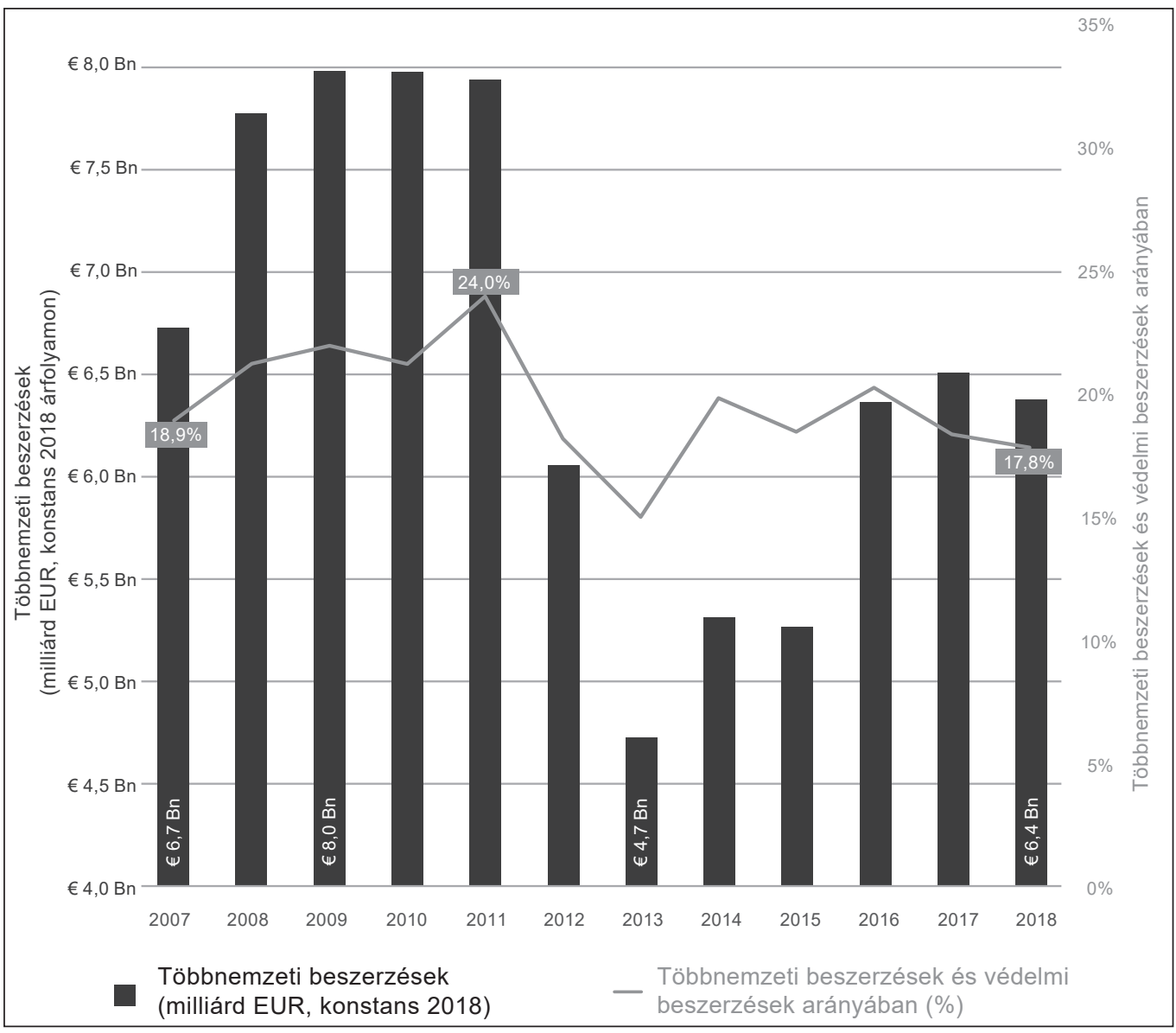

\section{4. ábra: Az EU tagállamainak többnemzeti eszközbeszerzésre fordított forrásai} és azok aránya a teljes védelmi költségvetésen belül, 2007-2018.

Forrás: EDA Defence Data 2017-2018. Key Findings and Analysis: 9.

Hasonlóan kedvezötlen trendet láthatunk a többnemzeti keretben folytatott védelmi kutatás-fejlesztés terén, ahol éppen a válság előtt kezdtek volna lendületet nyerni a közös fejlesztési projektek. A 2008-as történelmi csúcsról (453 millió euró, 2018-as konstans árfolyamon számolva) 2018-ra 66\%-kal csökkentek e források, 153 millió euróra. A többnemzeti $\mathrm{K}+\mathrm{F}$ és a nemzeti $\mathrm{K}+\mathrm{F}$ kiadások természetesen együtt csökkentek, és e téren is elmaradtak az EDA 2007-es célkitüzésétől, hogy az összegzett védelmi K + F kiadásokon belül 20\%-ot többnemzeti keretben használjanak fel (5. ábra). ${ }^{8}$

8 Defence Data 2017-2018. Key Findings and Analysis: 10. 


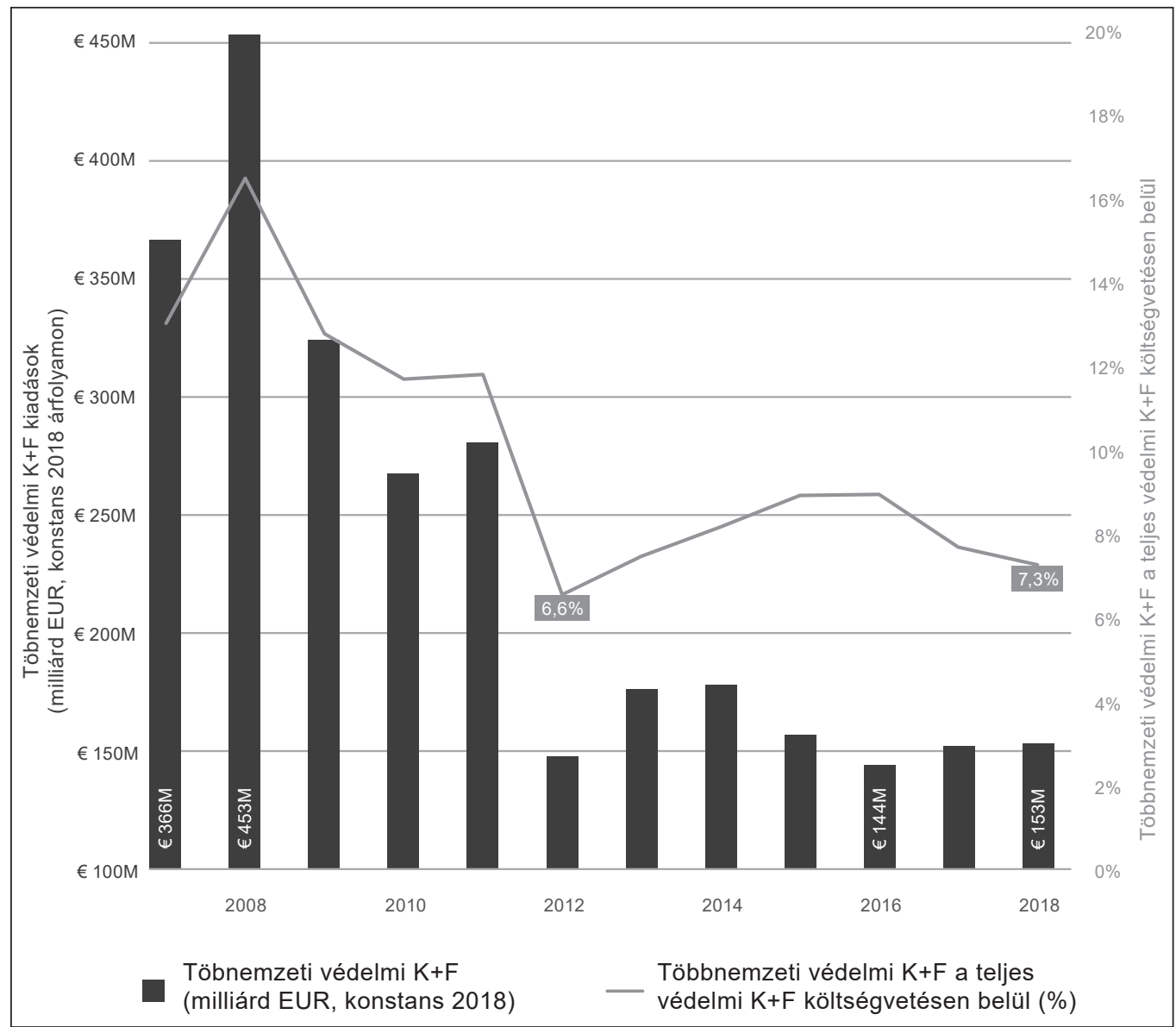

5. ábra: Az EU-tagállamok körében megvalósított többnemzeti védelmi kutatás-fejlesztés és annak aránya a teljes védelmi $\mathrm{K}$ + $\mathrm{F}$ költségvetésen belül, 2007-2018.

Forrás: EDA Defence Data 2017-2018. Key Findings and Analysis: 11.

\section{A NATO kimutatása}

Az Észak-atlanti Szerződés Szervezete a NATO vezetőinek december 3-4-ei londoni találkozója elött hozta nyilvánosságra a 2019-re vonatkozó legfrissebb becslésekkel kiegészített védelmi kiadási adatsorokat. Ez esetben is hasonló trendet látunk, mint az EDA adatainál: a szövetségben az összesített védelmi kiadások 2013-hoz (949 milliárd dollár) képest 5,6\%-os csökkenést követően 2015-ben érték el a mélypontot (896 milliárd dollár), majd fokozatos, összesen 10,15\%-os emelkedéssel 2019-ben 987 milliárd dollárra nőttek. Így ebben az évben sikerült ismét elérni, illetve meghaladni a 2013-as értéket (6. ábra). ${ }^{9}$ A NATO adatai annyiban hasznosak, hogy szélesebb perspektívába helyezik az európai államok tel-

9 Defence Expenditure of NATO Countries (2013-2019): 4. 
jesítményét. Fontos ugyanis jelezni, hogy a közkeletű kép ellenére a csökkenés ezekben az években elsősorban a NATO vezető hatalma, az Egyesült Államok védelmikiadás-csökkentésének volt a következménye, nem az európai tagállamokénak. Az amerikai védelmi költségvetés legalacsonyabb értéke 626 milliárd dollár volt 2017-ben, és a mélyponthoz képest 9,4\%-os növekedést jelentett.

Ha a teljes 2013-2019 közötti időszakot elemezzük, jól látható, hogy míg az Egyesült Államok katonai kiadásai 1,6\%-kal csökkentek, addig a többi tagállam 19,8\%-kal növelte védelmi kiadásait 2013-2019 között. Így az a kritika, hogy az európai szövetségesek nem növelik a kiadásaikat, már nem állt meg a lábán. Viszont továbbra is fennmaradt az aránytalanság az amerikai és a többi tagállam összesített teljesítménye között, még ha valamelyest javult is a tehermegosztás mérlege: 2013-ban 74: 26 volt ez az arány, 2019-ben pedig 69: 31 Washington „javára”.

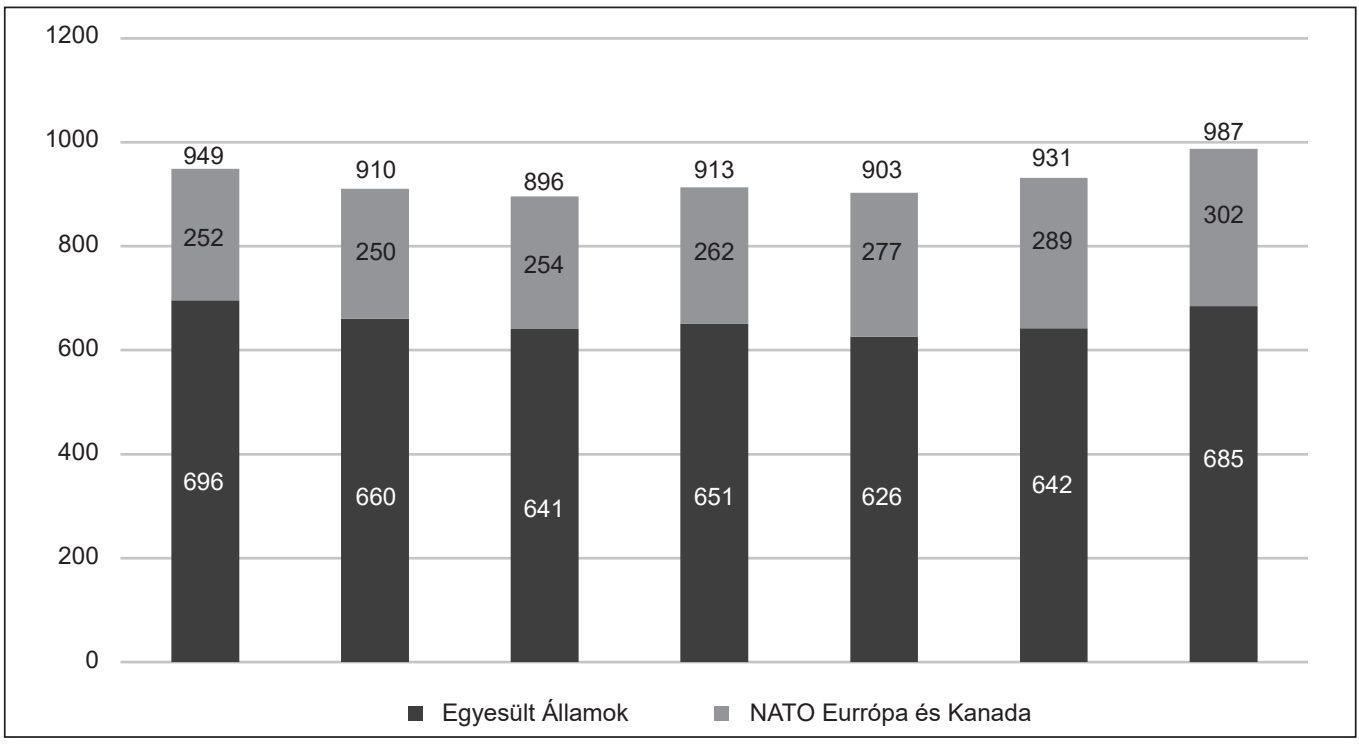

\section{6. ábra: Védelmi kiadási trendek a NAT0-ban, 2013-2019. (Milliárd dollár, konstans 2015-ös dollárárfolyamon. A 2019-es adat becslés.)}

Forrás: Defence Expenditure of NATO Countries (2013-2019): 4.

Ha az elmúlt éveket vetjük össze a NATO GDP-arányos 2\%-os célkitüzésének tükrében, akkor azt látjuk, hogy 2014-ban csupán három tagállam - az Egyesült Államok, NagyBritannia és Görögország - teljesítette azt, míg 2019-ben már kilenc: az Egyesült Államok, Nagy-Britannia, Görögország, Észtország, Lettország, Litvánia, Lengyelország, Románia és Bulgária. Átlagosan a NATO-tagállamok GDP-arányosan 1,67\%-ot költöttek védelemre 2019-ben. Ami a képességfejlesztésre fordítandó, a teljes védelmi költségvetésen belüli 20\%-os célkitüzést illeti, 2014-ben 7 tagállam, 2019-ben már 16 teljesítette, így átlagosan meghaladva (21,53\%) az iránymutatást (7. ábra).

A 20\%-ot meghaladó beszerzési kiadási tételek azt mutatják, hogy jelentős és széles körü modernizációs és képességfejlesztési programok zajlanak a NATO-n belül, aminek 
természetesen kézzel fogható eredménye akkor lesz, ha ez a pozitív mutató több éven át fennmarad, mert akkor nemcsak egy-egy aktuális fejlesztési program elindítását jelzi, hanem tudatos hosszú távú építkezést. Tekintettel arra, hogy mind a közép-európai, mind a balkáni tagállamok többnyire elöregedett haditechnikai eszközparkkal léptek be még a 2010-es évtizedbe is, illetve a skandináv és balti államok, valamint Lengyelország, kisebb mértékben pedig Románia is az érzékelt orosz hagyományos katonai fenyegetés miatt fegyverkezik, a megnövelt nagyságrendü beszerzések érthetök.

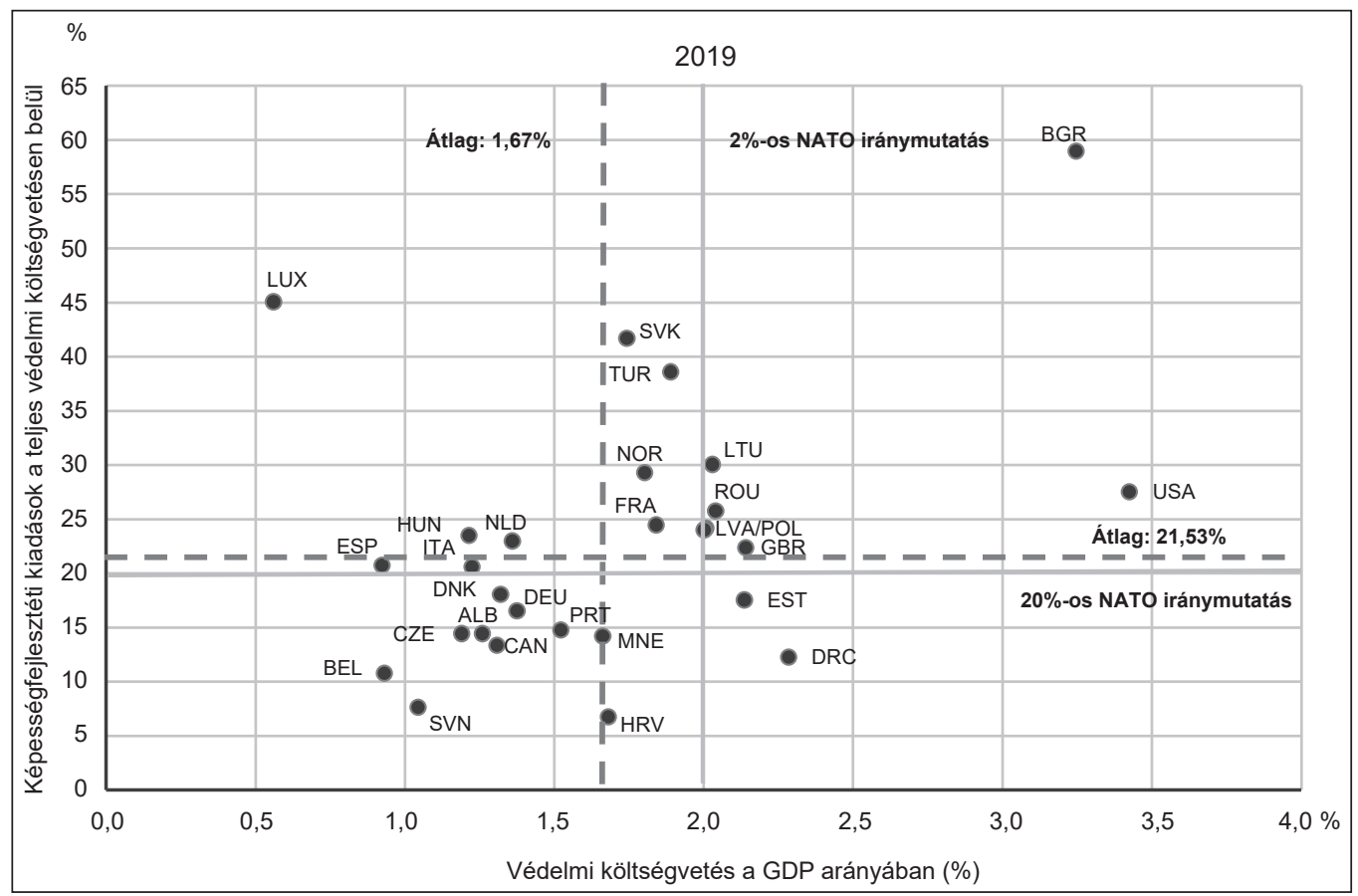

7. ábra: A NATO-tagállamok teljesítménye a 2\%-os és 20\%-os iránymutatás tekintetében 2019-ben.

Forrás: Defence Expenditure of NATO Countries (2013-2019): 4.

\section{FELHASZNÁLT IRODALOM}

Benchmarks, [online], 2019. 12. 16. Forrás: European Defence Agency [2020. 01. 23.]

Defence Data 2016-2017. Key Findings and Analysis, [online], 2018. 09. 07. Forrás: European Defence Agency [2020. 01. 23.]

Defence Data 2017-2018. Key Findings and Analysis, [online], 2019. 12. 16. Forrás: European Defence Agency [2020. 01.23.]

Defence Expenditure of NATO Countries (2013-2019), [online], 2019. 11. 12. Forrás: NATO Public Diplomacy Division [2020. 01. 23.] 